\title{
PENERAPAN MODEL PEMBELAJARAN LEARNING CYCLE 7E SEBAGAI UPAYA PENINGKATAN KEMAMPUAN BERPIKIR KRITIS DAN PRESTASI BELAJAR SISWA PADA SUB MATERI KONSEP MOL KELAS X MIA 2 SMA NEGERI 1 SUKOHARJO TAHUN PELAJARAN 2016/2017
}

\author{
Amalia Nur Hidayah, Widiastuti Agustina E S*, dan Budi Utami \\ Program Studi Pendidikan Kimia, FKIP,Universitas Sebelas Maret, Surakarta, Indonesia \\ Keperluan korespodensi, telp : 081280660500, email : widiastuti_aes@staff.uns.ac.id
}

\begin{abstract}
ABSTRAK
Penelitian ini bertujuan untuk meningkatkan kemampuan berpikir kritis dan prestasi belajar siswa kelas X MIA 2 SMA Negeri 1 Sukoharjo tahun pelajaran 2016/2017 pada sub materi konsep mol dengan menerapkan model pembelajaran Learning Cycle 7E. Penelitian ini merupakan Penelitian Tindakan Kelas (PTK) yang dilaksanakan dalam dua siklus, dengan setiap siklus terdapat empat tahapan yang terdiri dari perencanaan, pelaksanaan tindakan, observasi dan refleksi. Subjek penelitian ini adalah siswa kelas X MIA 2 SMA Negeri 1 Sukoharjo tahun pelajaran 2016/2017. Sumber data adalah informasi dari guru dan siswa, dokumen yang berhubungan dengan masalah penelitian, serta peristiwa dan perilaku siswa selama proses pembelajaran. Teknik pengumpulan data adalah dengan observasi, wawancara, tes dan angket, selanjutnya data dianalisis secara deskriptif kualitatif. Hasil penelitian menunjukkan bahwa pada siklus I, persentase siswa dengan kemampuan berpikir kritis tinggi adalah $57,5 \%$ dan meningkat menjadi $82,5 \%$ pada siklus II. Peningkatan prestasi belajar dapat dilihat dari aspek pengetahuan, aspek sikap dan aspek keterampilan. Pada aspek pengetahuan, persentase ketuntasan belajar siswa pada siklus I adalah $57,5 \%$ dan meningkat menjadi $95 \%$ pada siklus II. Pada aspek sikap, siswa dengan kategori minimal baik pada siklus I adalah $80 \%$ dan meningkat menjadi $92,5 \%$ pada siklus II. Persentase ketuntasan aspek keterampilan yang dilaksanakan pada siklus I adalah $100 \%$. Berdasarkan hasil penelitian dapat disimpulkan bahwa penerapan model pembelajaran Learning Cycle 7E dapat meningkatkan kemampuan berpikir kritis dan prestasi belajar siswa pada sub materi konsep mol di kelas X MIA 2 SMA Negeri 1 Sukoharjo tahun pelajaran 2016/2017.
\end{abstract}

Kata kunci: penelitian tindakan kelas, learning cycle 7E, kemampuan berpikir kritis, prestasi belajar, sub materi konsep mol.

\section{PENDAHULUAN}

Sistem pendidikan di Indonesia mengacu pada Undang-Undang Nomor 20 Tahun 2003 tentang Sistem Pendidikan Nasional. Di dalam sistem pendidikan nasional terdapat komponenkomponen pendidikan yang saling berkaitan untuk mencerdaskan dan memperbaiki kualitas hidup rakyat Indonesia. Kualitas komponen pendidikan akan mempengaruhi mutu proses pembelajaran, dan mutu proses pembelajaran akan mempengaruhi kualitas pendidikan [1]. Saat ini, pembelajaran di sekolah sudah harus berorientasi pada PAIKEM, yaitu pembelajaran aktif, inovatif, kreatif, efektif dan menyenangkan. Pembelajaran seperti ini dapat meningkatkan kualitas pembelajaran itu sendiri.

Model pembelajaran merupakan suatu hal yang dapat menunjang PAIKEM di sekolah. Adanya model pembelajaran dalam proses pembelajaran dapat mempengaruhi emosi siswa dalam belajar. Emosi siswa akan berdampak pada pemahaman materimateri yang diberikan oleh guru. Model pembelajaran akan memberikan kesan yang berbeda bagi siswa dalam belajar di sekolah dan memudahkan siswa dalam 
memahami materi yang disampaikan oleh guru.

Pada Kurikulum 2013, pembelajaran yang seharusnya terjadi di kelas adalah pembelajaran yang berpusat pada siswa (students center) dan siswa dituntut untuk paham semua materi, aktif dalam berdiskusi dan sopan santun dalam perilakunya. SMA Negeri 1 Sukoharjo adalah salah satu sekolah yang sudah menerapkan Kurikulum 2013 dalam proses pembelajarannya. Berdasarkan wawancara yang telah dilakukan dengan salah satu guru kimia di SMA Negeri 1 Sukoharjo, model pembelajaran selain ceramah yang diterapkan di kelas hanya sebatas diskusi kelompok. Model pembelajaran tersebut masih bersifat sederhana dan kurang inovatif. Metode ceramah juga masih mendominasi dalam penyampaian materi yang diajarkan. Observasi yang dilakukan di kelas X MIA 2 SMA Negeri 1 Sukoharjo menunjukkan kurangnya semangat belajar siswa pada pembelajaran kimia yang menerapkan model pembelajaran diskusi yang sederhana dan kurang inovatif. Model pembelajaran tersebut kurang menarik perhatian dan menimbulkan rasa jenuh bagi siswa, serta dapat menimbulkan suasana belajar yang tidak kondusif. Dapat dikatakan bahwa penerapan model pembelajaran inovatif dalam proses pembelajaran di sekolah tersebut belum dilakukan secara maksimal.

Kimia merupakan salah satu mata pelajaran yang diajarkan di Sekolah Menengah Atas (SMA) atau Madrasah Aliyah (MA), dan termasuk salah satu materi yang dianggap sulit. Kimia adalah cabang ilmu pengetahuan yang mempelajari struktur materi, sifat-sifat materi, perubahan suatu materi menjadi materi lain, serta energi yang menyertai perubahan materi [2]. Dari definisi tersebut kimia dapat disebut sebagai ilmu mikro dan abstrak, yaitu ilmu yang mempelajari sesuatu yang tidak dapat dilihat dan tidak disadari keberadaannya dalam kehidupan sehari-hari, akan tetapi perubahan-perubahan kimia dapat diamati. Mempelajari kimia sama dengan mempelajari bahasa baru, karena dipelajari juga simbol-simbol baru yang belum banyak diketahui dalam kehidupan sehari-harinya. Selain itu, dalam pembelajaran kimia bukan hanya teori saja yang dipelajari, tetapi perhitungan matematika juga termasuk di dalamnya. Salah satu materi kimia yang mempelajari teori dan perhitungan matematika adalah stoikiometri.

Stoikiometri merupakan materi yang sulit bagi siswa. Hal ini dibuktikan dengan data hasil belajar siswa SMA Negeri 1 Sukoharjo pada materi tersebut selama dua tahun terakhir yang dapat dilihat pada Tabel 1. Data tersebut menunjukkan hasil yang kurang memuaskan.

Tabel 1. Hasil Belajar Siswa SMA Negeri 1 Sukoharjo Materi Stoikiometri

\begin{tabular}{ccc}
\hline \multirow{2}{*}{ Kelas } & \multicolumn{2}{c}{ Persentase Ketuntasan } \\
\cline { 2 - 3 } & $2014 / 2015$ & $2015 / 2016$ \\
\hline X MIA 1 & $68,9 \%$ & $67,1 \%$ \\
X MIA 2 & $62,5 \%$ & $54,4 \%$ \\
X MIA 3 & $53,3 \%$ & $60,2 \%$ \\
X MIA 4 & $60,2 \%$ & $59,2 \%$ \\
\hline
\end{tabular}

Pada materi stoikiometri terdapat proses perhitungan kimia yang berkaitan dengan konsep-konsep di awal materi, seperti pada sub materi konsep mol. Konsep-konsep tersebut harus dipahami dengan baik agar dapat menyelesaikan perhitungan kimia dengan benar. Siswa yang mengalami kesulitan dalam sub materi konsep mol ini dapat dilihat pada hasil belajar materi sebelumnya, yaitu struktur atom dan sistem periodik unsur. Pada materi struktur atom dan sistem periodik unsur terdapat konsep-konsep yang harus dipahami dengan baik seperti lambang atom, konfigurasi elektron, elektron valensi dan kestabilan atom, yang nantinya konsep tersebut dijadikan konsep dasar pada sub materi konsep mol, yaitu pada penulisan persamaan reaksi yang setara. Di kelas X MIA 2 SMA Negeri 1 Sukoharjo tahun pelajaran 2016/2017, ketuntasan nilai siswa pada materi struktur atom dan sistem periodik unsur termasuk rendah. Hanya 55\% siswa yang tuntas atau memenuhi KKM dari total 40 siswa. Hal tersebut menimbulkan dugaan bahwa siswa akan mengalami kesulitan pada sub materi 
konsep mol. Selain itu, siswa juga akan mengalami kesulitan pada materi-materi selanjutnya seperti termokimia, asambasa, kesetimbangan kimia dan lain sebagainya, karena stoikiometri merupakan materi yang mendasari materi-materi tersebut. Maka dari itu apabila prestasi belajar siswa pada sub materi konsep mol tidak segera diantisipasi, akan mempengaruhi prestasi belajar siswa pada materi-materi yang berkaitan.

Hasil wawancara menunjukkan bahwa terdapat hal lain yang mempengaruhi rendahnya prestasi belajar siswa pada sub materi konsep mol adalah rendahnya kemampuan berpikir kritis siswa. Pernyataan tersebut dibuktikan dengan hasil angket kemampuan berpikir kritis siswa kelas X MIA 2 SMA Negeri 1 Sukoharjo. Berdasarkan hasil yang didapat, sebanyak $60 \%$ dari total siswa memiliki kemampuan berpikir kritis rendah, 2,5\% memiliki kemampuan berpikir kritis sangat rendah dan sisanya memiliki kemampuan berpikir kritis tinggi. Sub materi konsep mol menuntut siswa untuk mampu berpikir secara kritis dalam menerapkan konsep-konsep yang telah dijelaskan di awal untuk dapat menyelesaikan suatu perhitungan kimia yang aplikatif dan berkembang.

Model pembelajaran yang dapat meningkatkan kemampuan berpikir kritis dan prestasi belajar siswa salah satunya adalah Learning Cycle (LC) 7E. Model pembelajaran ini dapat meningkatkan kemampuan berpikir kritis dalam pembelajaran kimia [3]. Model pembelajaran ini juga dapat meningkatkan kemampuan berpikir kritis siswa pada pembelajaran IPA [4]. Selain itu, model pembelajaran LC 7E merupakan model pembelajaran yang sesuai dan berguna dalam pembelajaran IPA [5]. Model pembelajaran ini merupakan student center learning, yang berarti bahwa proses pembelajarannya berpusat pada siswa. Model pembelajaran LC 7E sesuai untuk diterapkan dalam pembelajaran yang berbasis Kurikulum 2013. Tahap-tahap kegiatan tersebut yaitu Elicit, Engagement, Exploration, Explanation, Elaboration, Evaluation dan Extend [6]. Model pembelajaran LC merupakan model pembelajaran yang terdiri dari tahap-tahap kegiatan yang diatur sedemikian rupa agar siswa berperan aktif dalam kegiatan pembelajaran dan memudahkan siswa dalam memahami materi-materi yang diberikan oleh guru. Model pembelajaran LC 7E merupakan model pembelajaran yang lebih efektif daripada model pembelajaran konvensional dalam peningkatan prestasi belajar siswa [7].

\section{METODE PENELITIAN}

Penelitian ini merupakan Penelitian Tindakan Kelas (PTK) yang dilaksanakan dalam dua siklus. Setiap siklusnya terdapat empat tahapan, yaitu perencanaan, pelaksanaan, observasi, dan refleksi. Subjek penelitian adalah siswa kelas X MIA 2 SMA Negeri 1 Sukoharjo tahun pelajaran 2016/2017. Pemilihan subjek dalam penelitian ini didasarkan pada hasil kajian dokumen, observasi dan angket prasiklus, dimana subjek yang dipilih tersebut teridentifikasi mempunyai permasalahan dalam pembelajaran yaitu kemampuan berpikir kritis dan prestasi belajar yang rendah.

Data yang dikumpulkan meliputi data kemampuan berpikir kritis dan prestasi belajar siswa yang mencakup aspek pengetahuan, aspek sikap dan aspek keterampilan baik pada siklus I maupun siklus II.

Analisis data menggunakan tiga tahap yaitu reduksi data (pengelolaan data), penyajian data (mengorganisasikan data kedalam suatu bentuk tertentu sehingga datanya terlihat lebih utuh), dan triangulasi atau pemeriksaan keabsahan data dengan memanfaatkan sesuatu yang lain di luar data tersebut sebagai pembanding data [8].

\section{HASIL DAN PEMBAHASAN}

Hasil dari observasi dan angket pra siklus, wawancara, serta kajian dokumen menunjukkan bahwa kemampuan berpikir kritis dan prestasi belajar siswa masih tergolong rendah pada materi stoikiometri. Selain itu, proses pembelajaran yang berpusat pada siswa belum dilaksanakan secara maksimal sehingga kualitas pembelajaran masih kurang. 


\section{Siklus I}

\section{a. Perencanaan}

Pada tahap perencanaan siklus I dilakukan penyusunan silabus, RPP yang sesuai dengan sintaks model pembelajaran LC 7E, instrumen penilaian kemampuan berpikir kritis, serta instrumen prestasi belajar. Pembelajaran pada siklus I dilaksanakan sebanyak 4 kali pertemuan atau 8 jam pelajaran, yaitu 6 jp ( $6 \times 45$ menit) untuk penyampaian materi dan 2 jp $(2 \times 45$ menit) untuk evaluasi siklus I.

\section{b. Pelaksanaan}

Tahap pelaksanaan siklus I terdiri atas 4 kali pertemuan, dengan 3 kali pertemuan untuk penyampaian materi dan 1 kali pertemuan untuk evaluasi siklus I. Pada pertemuan pertama ini guru memulai pembelajaran dengan materi konsep mol, massa molar, volume molar, molaritas dan konversinya. Pada awal kegiatan pembelajaran guru memulai pelajaran dengan memberikan apersepsi mengenai materi yang akan dipelajari. Selanjutnya guru menyam-paikan tujuan pembelajaran serta manfaat mempelajari materi pada pertemuan tersebut. Guru memulai kegiatan inti dengan membuat kelompok yang terdiri dari 5 siswa heterogen. Pembentukan kelompok terdiri dari siswa berdasarkan urutan absen.

Siswa melakukan kegiatan mengamati, menanya, mengumpulkan data, mengasosiasi dan mengkomunikasikan selama kegiatan inti berlangsung. Pada kegiatan mengamati, tidak semua siswa memperhatikan penjelasan guru dengan baik, sehingga pada saat merumuskan kesimpulan dari penjelasan tersebut, ada beberapa siswa yang diam dan tidak dapat mengikuti siswa yang memahami penjelasan guru. Pada kegiatan menanya, siswa yang belum memahami penjelasan dari guru dapat bertanya, akan tetapi tidak ada siswa yang bertanya kepada guru. Pada kegiatan mengumpulkan data yang dilakukan secara berkelompok, masih ada beberapa kelompok yang hanya menggunakan satu sumber data. Kegiatan diskusi berkelompok pada pertemuan pertama berlangsung kurang kondusif karena siswa baru memulai adaptasi dengan kelompoknya masingmasing. Pada kegiatan mengasosiasi, setiap kelompok menuliskan hasil penyelidikannya dengan bahasa sendiri dan menerapkannya dalam permasalahan atau soal yang diberikan oleh guru. Setiap kelompok sudah melaksanakan kegiatan ini dengan baik. Setiap siswa dalam satu kelompok bekerja sama dan saling membantu dalam menyelesaikan permasalahan atau soal tersebut. Akan tetapi, masih ada beberapa siswa dalam kelompok yang pasif dalam berdiskusi dengan siswa lain. Pada kegiatan mengkomunikasikan, beberapa perwakilan dari setiap kelompok menyampaikan hasil diskusinya dengan cara mempresentasikan kepada kelompok lain di depan kelas. Ada beberapa kelompok yang tidak memperhatikan presentasi yang dilakukan oleh kelompok lain karena sibuk dengan diskusinya masing-masing, namun ada juga kelompok yang memberikan tanggapan karena terdapat perbedaan pendapat. Pada kegiatan ini guru juga memberikan penilaian terhadap hasil presentasi yang dilakukan oleh setiap kelompok dan tanggapan dari kelompok lain. Pada kegiatan penutup, siswa dibantu oleh guru untuk menyimpulkan konsep inti dari materi yang telah disampaikan sebagai bentuk penguatan dan mem-perluas materi dengan mengaitkan materi yang dipelajari hari ini dengan materi sebelumnya. Kegiatan pem-belajaran diakhiri dengan siswa menger-jakan soal posttest yang diberikan oleh guru sebagai evaluasi pemahaman materi pada pertemuan tersebut. Dari hasil evaluasi dapat terlihat bahwa tidak semua siswa memahami kegiatan pembelajaran pada pertemuan ini dengan baik.

Pelaksanaan pembelajaran pada pertemuan kedua dan ketiga hampir sama dengan pertemuan pertama, akan tetapi pada pertemuan ketiga siswa diberikan tugas sebagai penilaian aspek keterampilan. Selain itu, siswa melaksanakan kegiatan pembelajaran dengan lebih baik dibanding pada pertemuan pertama, yaitu siswa lebih aktif dalam bertanya dan berdiskusi. Pada pertemuan keempat, dilaksanakan evaluasi 
siklus I yang meliputi penilaian kemampuan berpikir kritis, aspek pengetahuan dan angket penilaian diri.

\section{c. Pengamatan}

Hasil observasi dan data penilaian yang diperoleh dalam siklus I adalah kemampuan berpikir kritis dan prestasi belajar siswa yang meliputi aspek pengetahuan, aspek sikap dan aspek keterampilan. Hasil penilaian kemampuan berpikir kritis dapat dilihat pada Gambar 1.

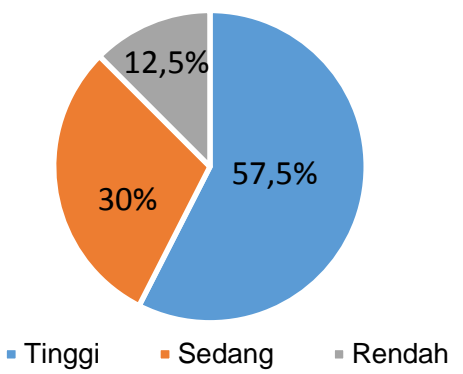

Gambar 1. Hasil Penilaian Kemampuan Berpikir Kritis Siswa Siklus I

Ketercapaian kemampuan berpikir kritis dilihat berdasarkan kategori tinggi, sehingga ketercapaian kemampuan berpikir kritis siswa kelas X MIA 2 adalah $57,5 \%$. Persentase ketercapian ini belum memenuhi target yang ditetapkan yaitu $75 \%$.

Tabel 2: Hasil Penilaian Per Indikator Kemampuan Berpikir Kritis Siswa Siklus I

\begin{tabular}{|c|c|c|}
\hline No. & Indikator & $\begin{array}{c}\text { Capaian } \\
(\%)\end{array}$ \\
\hline 1. & Mengidentifikasi asumsi & 77,5 \\
\hline 2. & $\begin{array}{l}\text { Membedakan informasi yang } \\
\text { relevan dan tidak relevan }\end{array}$ & 75 \\
\hline 3. & $\begin{array}{l}\text { Mendeduksi dan } \\
\text { mempertimbangkan hasil } \\
\text { deduksi }\end{array}$ & 45 \\
\hline 4. & $\begin{array}{l}\text { Menginduksi dan } \\
\text { mempertimbangkan hasil } \\
\text { induksi }\end{array}$ & 80 \\
\hline 5. & $\begin{array}{l}\text { Mempertimbangkan } \\
\text { wawasan lain }\end{array}$ & 77,5 \\
\hline 6. & $\begin{array}{l}\text { Membedakan fakta dan } \\
\text { pendapat }\end{array}$ & 58,75 \\
\hline 7. & $\begin{array}{l}\text { Menarik kesimpulan } \\
\text { berdasarkan data }\end{array}$ & 73,75 \\
\hline 8. & Memberikan alternatif pilihan & 80 \\
\hline 9. & $\begin{array}{l}\text { Menentukan tindakan yang } \\
\text { akan dilakukan }\end{array}$ & 67,5 \\
\hline
\end{tabular}

Indikator kemampuan berpikir kritis yang belum tercapai pada siklus I yaitu menginduksi dan mempertimbangkan hasil induksi, membedakan fakta dan pendapat, menarik kesimpulan berdasarkan data dan menentukan tindakan yang akan dilakukan mempengaruhi belum tercapainya aspek pengetahuan pada kegiatan pembelajaran siklus I. Siswa yang belum sepenuhnya memahami sub materi konsep mol sulit menentukan langkah akhir pengerjaan soal pada tes aspek pengetahuan siklus I.

Hasil penilaian aspek pengetahuan dapat dilihat pada Gambar 2.

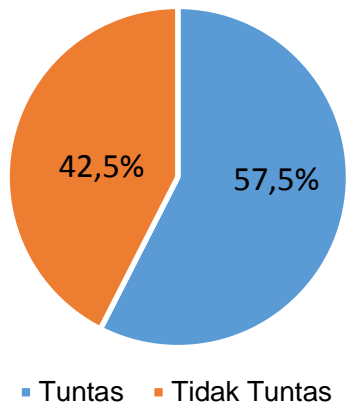

Gambar 2. Hasil Penilaian Aspek Pengetahuan Siswa Siklus I

Gambar 2 menunjukkan bahwa siswa yang tuntas atau mencapai nilai KKM yaitu 57,5\%. Hasil ini belum memenuhi target yang ditetapkan yaitu $75 \%$. Terdapat 3 indikator yang belum mencapai target, yaitu menjelaskan pengertian mol sebagai satuan jumlah zat, menentukan rumus empiris dan rumus molekul, serta menentukan pereaksi pembatas dalam reaksi kimia yang dapat dilihat pada Tabel 3 . Ketuntasan nilai siswa yang belum mencapai target dapat disebabkan karena pemahaman siswa yang kurang mengenai sub materi konsep mol. Hal ini dapat disebabkan karena pembagian kelompok pada kegiatan pembelajaran siklus I didasarkan pada urutan absen, sehingga kemampuan siswa dalam satu kelompok kurang heterogen. Kemampuan siswa dalam satu kelompok mempengaruhi pemahaman siswa mengenai sub materi konsep mol. 
Tabel 3. Hasil Penilaian Per Indikator Aspek Pengetahuan Siswa Siklus I

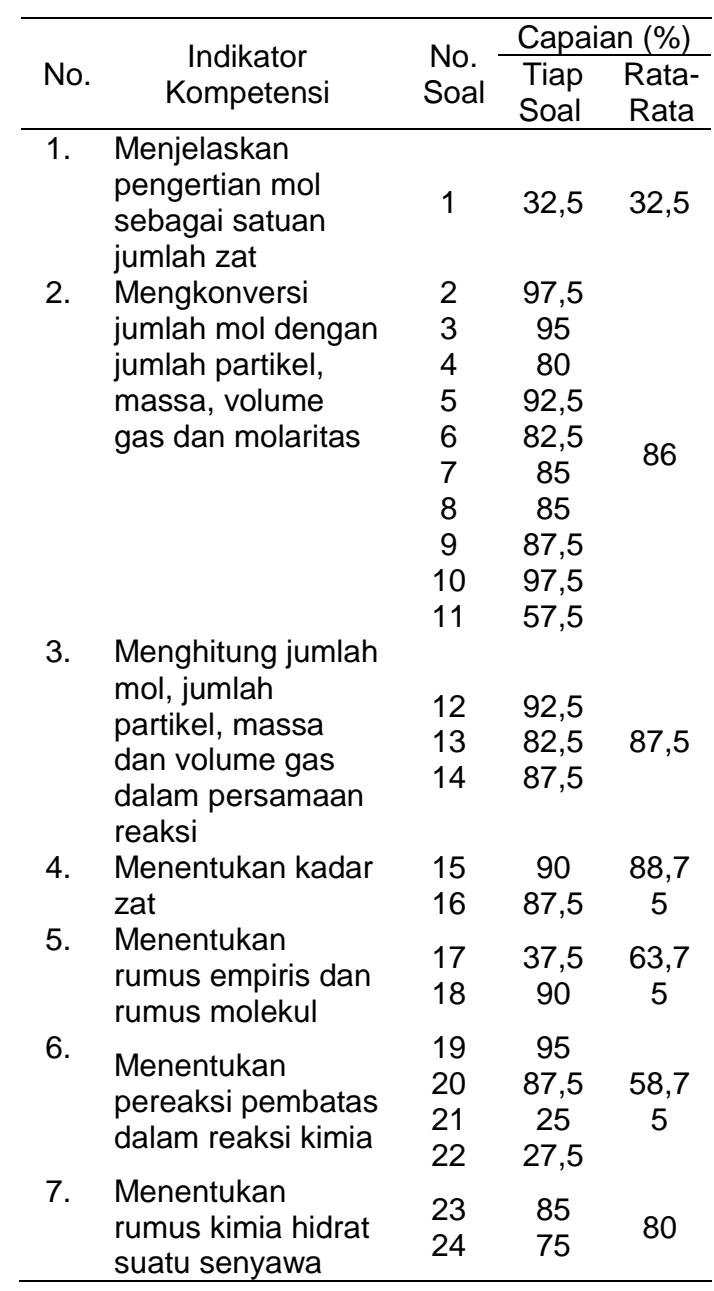

Aspek sikap siswa yang dinilai adalah sikap spiritual dan sikap sosial yang meliputi sikap jujur, rasa ingin tahu, tanggung jawab dan kerjasama. Hasil penilaian aspek sikap siswa dapat dilihat pada Gambar 3.

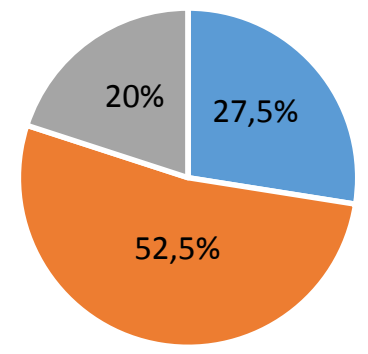

- Sangat Baik - Baik - Cukup Baik - Kurang Baik

Gambar 3. Hasil Penilaian Aspek Sikap Siswa Siklus I

Gambar 3 menunjukkan jika ketercapaian aspek sikap siswa sebesar $80 \%$. Ketercapaian yang diperoleh merupakan akumulasi persentase siswa kategori sangat baik dan baik. Ketercapaian ini sudah mencapai target yang ditetapkan yaitu 75\%. Akan tetapi ketercapaian indikator sikap jujur dan rasa ingin tahu belum mencapai target, sehingga perlu diperbaiki atau ditingkatkan pada siklus II. Belum tercapainya aspek sikap jujur dikarenakan ada beberapa siswa yang mencontek hasil pekerjaan teman lain seperti saat mengerjakan soal posttest. Hal ini dapat disebabkan karena siswa masih belum memahami materi yang disampaikan oleh guru dengan baik. Kurangnya pemahaman materi pada siswa dapat disebabkan karena rasa ingin tahu yang kurang.

Penilaian aspek keterampilan menunjukkan bahwa ketuntasan nilai siswa telah mencapai target, yaitu $100 \%$. Target yang ditetapkan adalah $75 \%$ siswa yang tuntas.

\section{d. Refleksi}

Hasil penelitian kegiatan pembelajaran siklus I menunjukkan bahwa masih terdapat kekurangan yang menyebabkan aspek kemampuan berpikir kritis dan pengetahuan belum mencapai target yang diharapkan. Aspek sikap yang berupa jujur dan rasa ingin tahu yang belum mencapai target pada kegiatan pembelajaran siklus I. Maka dari itu perlu dilaksanakan pembelajaran siklus II yang diharapkan dapat memperbaiki atau meningkatkan kemampuan berpikir kritis siswa dan prestasi belajar siswa sehingga mencapai target yang sudah ditetapkan.

\section{Siklus II}

\section{a. Perencanaan}

Pelaksanaan pembelajaran siklus II adalah sebagai tindak lanjut untuk menyempurnakan dan memperbaiki kekurangan-kekurangan pada kegiatan pembelajaran siklus I. Materi yang diberikan berfokus pada indikator aspek pengetahuan yang belum mencapai target yaitu menjelaskan pengertian mol sebagai satuan jumlah zat, menentukan rumus empiris dan rumus molekul, serta menentukan pereaksi pembatas dalam 
reaksi kimia Tindakan yang dilakukan pada kegiatan pembelajaran siklus II antara lain mengganti pembagian kelompok berdasarkan hasil tes aspek pengetahuan siklus I, guru lebih mendorong siswa dalam mengajukan pertanyaan mengenai hal-hal yang belum mereka pahami, serta guru lebih memperhatikan siswa yang mengalami kesulitan dalam memahami materi dan mendapatkan nilai dibawah KKM pada siklus I. Perubahan pembagian kelompok dilakukan agar kemampuan siswa dalam satu kelompok menjadi heterogen sehingga siswa yang memiliki kemampuan yang baik dapat membantu siswa yang memiliki kemampuan yang kurang dalam memahami sub materi konsep mol dengan baik.

\section{b. Pelaksanaan}

Pembelajaran pada siklus II dilaksanakan sebanyak 2 kali pertemuan atau 4 jam pelajaran, yaitu 2 jp $(2 \times 45$ menit) untuk penyampaian materi dan 2 jp (2 x 45 menit) untuk evaluasi siklus II. Pada awal pembelajaran pertemuan pertama, guru memberikan apersepsi untuk mengingatkan siswa pada materi sebelumnya. Kemudian guru menyampaikan tujuan pembelajaran dan manfaat mempelajari materi yang akan diberikan untuk meningkatkan motivasi siswa.

Pada kegiatan mengamati, siswa memperhatikan penjelasan guru mengenai konsep mol, kemudian bersama dengan guru menyelesaikan soal konsep mol terutama pada rumus empiris dan rumus molekul, serta pereaksi pembatas. Ada siswa yang mampu mengikuti dengan baik namun ada juga siswa yang diam dan tidak dapat mengikuti dengan baik. Pada kegiatan menanya, siswa yang belum memahami penjelasan dari guru dapat bertanya. Banyak siswa yang bertanya kepada guru mengenai penyelesaian soal yang dijelaskan oleh guru. Pada kegiatan mengumpulkan data, siswa menerima lembar kerja dari guru kemudian memahami soal-soal dalam lembar kerja tersebut dan menyelidiki kesulitan-kesulitan yang akan didapat secara berkelompok. Pada kegiatan mengasosiasi, siswa di dalam kelompok saling berbagi tentang pemahaman materi yang telah dipelajari dengan bahasanya masing-masing dalam rangka menyelesaikan soal-soal pada lembar kerja siswa. Setiap kelompok mengerjakan soal yang terdapat pada lembar kerja tersebut berdasarkan pemahaman yang dimilikinya. Pembagian kelompok berdasarkan kemampuan siswa dalam memahami materi, sehingga dalam kegiatan diskusi kelompok ini siswa aktif berdiskusi dan siswa yang belum memahami materi dengan baik dibantu oleh siswa lain sampai menemukan penyelesaian masalahnya. Pada kegiatan mengkomunikasikan, beberapa perwakilan dari setiap kelompok menyampaikan hasil diskusinya dengan cara mempresentasikan kepada kelompok lain di depan kelas. Kelompok lain memperhatikan presentasi yang dilakukan oleh suatu kelompok dengan baik dan ada beberapa kelompok yang memberikan tanggapan karena terdapat perbedaan pendapat. Pada kegiatan ini guru juga memberikan penilaian terhadap hasil presentasi yang dilakukan oleh setiap kelompok dan tanggapan dari kelompok lain. Pada kegiatan penutup, siswa dibantu oleh guru untuk menyimpulkan konsep inti dari materi yang telah disampaikan sebagai bentuk penguatan dan memperluas materi bahwa konsep mol dan perhitungan kimia ini akan digunakan pada materi yang akan dipelajari selanjutnya, seperti termokimia, asam basa dan lain sebagainya. Kegiatan pembelajaran diakhiri dengan siswa mengerjakan soal posttest yang diberikan oleh guru sebagai evaluasi pemahaman materi pada pertemuan tersebut. Berdasarkan hasil evaluasi pada pertemuan ini, sebagian besar siswa sudah memahami materi rumus empiris dan rumus molekul, serta pereaksi pembatas dengan baik.

Pada pertemuan kedua dilaksanakan evaluasi siklus II yang meliputi penilaian kemampuan berpikir kritis dan aspek pengetahuan.

\section{Pengamatan}

Hasil observasi dan data penilaian yang diperoleh dalam siklus II adalah 
kemampuan berpikir kritis dan prestasi belajar siswa yang meliputi aspek pengetahuan dan aspek sikap. Hasil penilaian kemampuan berpikir kritis dengan kategori tinggi, sedang dan rendah dapat dilihat pada Gambar 4.

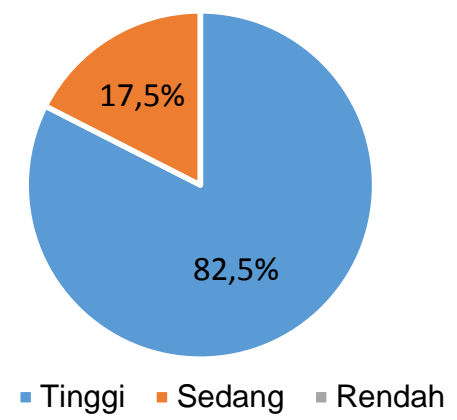

Gambar 4. Hasil Penilaian Kemampuan Berpikir Kritis Siswa Siklus II

Ketercapaian kemampuan berpikir kritis siswa kelas X MIA 2 pada siklus II adalah $82,5 \%$. Persentase ketercapian ini telah memenuhi target yang ditetapkan. Selain itu, persentase ketuntasan per indikator juga sudah mencapai target tersebut.

Tabel 4: Hasil Penilaian Per Indikator Kemampuan Berpikir Kritis Siswa Siklus II

\begin{tabular}{|c|c|c|}
\hline No. & Indikator & $\begin{array}{c}\text { Capaian } \\
(\%)\end{array}$ \\
\hline 1. & Mengidentifikasi asumsi & 77,5 \\
\hline 2. & $\begin{array}{l}\text { Membedakan informasi } \\
\text { yang relevan dan tidak } \\
\text { relevan }\end{array}$ & 75 \\
\hline 3. & $\begin{array}{l}\text { Mendeduksi dan } \\
\text { mempertimbangkan hasil } \\
\text { deduksi }\end{array}$ & 77,5 \\
\hline 4. & $\begin{array}{l}\text { Menginduksi dan } \\
\text { mempertimbangkan hasil } \\
\text { induksi }\end{array}$ & 80 \\
\hline 5. & $\begin{array}{l}\text { Mempertimbangkan } \\
\text { wawasan lain }\end{array}$ & 77,5 \\
\hline 6. & $\begin{array}{l}\text { Membedakan fakta dan } \\
\text { pendapat }\end{array}$ & 80 \\
\hline 7. & $\begin{array}{l}\text { Menarik kesimpulan } \\
\text { berdasarkan data }\end{array}$ & 90 \\
\hline 8. & $\begin{array}{l}\text { Memberikan alternatif } \\
\text { pilihan }\end{array}$ & 80 \\
\hline 9. & $\begin{array}{l}\text { Menentukan tindakan } \\
\text { yang akan dilakukan }\end{array}$ & 82,5 \\
\hline
\end{tabular}

Hasil penilaian aspek pengetahuan dapat dilihat pada Gambar 5.

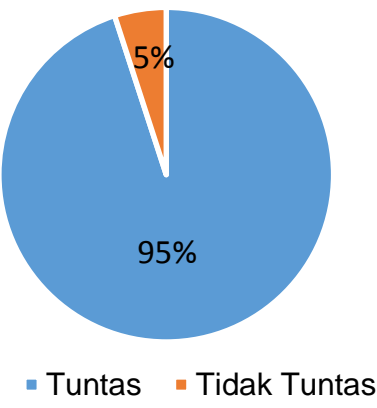

Gambar 5. Hasil Penilaian Aspek Pengetahuan Siswa Siklus II

Gambar 5 menunjukkan bahwa siswa yang tuntas atau mencapai nilai KKM adalah 95\%. Hasil ini telah memenuhi target yang ditetapkan. Selain itu, persentase ketuntasan per indikator aspek pengetahuan pada siklus II ini juga sudah mencapai target tersebut dan dapat dilihat pada Tabel 5 .

\begin{tabular}{|c|c|c|c|c|}
\hline \multirow[t]{2}{*}{ No. } & \multirow{2}{*}{$\begin{array}{l}\text { Indikator } \\
\text { Kompetensi }\end{array}$} & \multirow{2}{*}{$\begin{array}{l}\text { No. } \\
\text { Soal }\end{array}$} & \multicolumn{2}{|c|}{ Capaian (\%) } \\
\hline & & & $\begin{array}{l}\text { Tiap } \\
\text { Soal }\end{array}$ & $\begin{array}{l}\text { Rata- } \\
\text { Rata }\end{array}$ \\
\hline 1. & $\begin{array}{l}\text { Menjelaskan } \\
\text { pengertian } \\
\text { mol sebagai } \\
\text { satuan jumlah } \\
\text { zat }\end{array}$ & 1 & 80 & 80 \\
\hline 2. & $\begin{array}{l}\text { Menentukan } \\
\text { rumus empiris } \\
\text { dan rumus } \\
\text { molekul }\end{array}$ & $\begin{array}{l}2 \\
3 \\
4 \\
5 \\
6\end{array}$ & $\begin{array}{c}95 \\
100 \\
77,5 \\
100 \\
75\end{array}$ & 89,5 \\
\hline 3. & $\begin{array}{l}\text { Menentukan } \\
\text { pereaksi } \\
\text { pembatas } \\
\text { dalam reaksi } \\
\text { kimia }\end{array}$ & $\begin{array}{c}7 \\
8 \\
9 \\
10\end{array}$ & $\begin{array}{c}100 \\
100 \\
90 \\
87,5\end{array}$ & 94,38 \\
\hline
\end{tabular}

Aspek sikap siswa yang dinilai pada siklus II sama seperti pada siklus I. Hasil penilaian aspek sikap siswa dapat dilihat pada Gambar 6.

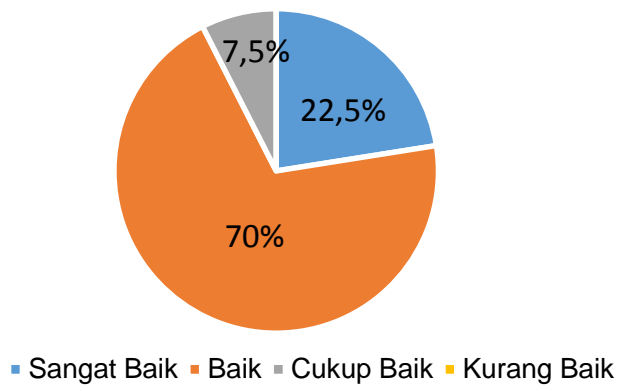

Gambar 6. Hasil Penilaian Aspek Sikap Siswa Siklus II 
Gambar 6 menunjukkan bahwa ketercapaian aspek sikap siswa adalah $92,5 \%$. Ketercapaian yang diperoleh merupakan akumulasi persentase siswa kategori sangat baik dan baik. Ketercapaian ini sudah mencapai target yang ditetapkan.

\section{d. Refleksi}

Berdasarkan hasil pengamatan dan evaluasi yang dilaksanakan pada siklus II, ketercapaian penilaian kemampuan berpikir kritis, aspek pengetahuan, aspek sikap dan aspek keterampilan telah mencapai target yang telah ditetapkan dan terjadi peningkatan pada setiap aspek.

\section{Perbandingan Antar Siklus}

Berdasarkan hasil observasi, angket, tes dan wawancara yang telah dilakukan pada siklus I dan siklus II dengan menggunakan model pembelajaran Learning Cycle 7E maka hasil tersebut dapat dibandingkan untuk mengetahui peningkatan yang terjadi pada setiap penilaian.

Persentase ketercapian kemampuan berpikir kritis siswa mengalami peningkatan dari siklus I ke siklus II. Pada siklus I, persentase siswa yang memiliki kemampuan berpikir kritis tinggi adalah sebesar $57,5 \%$ dan meningkat menjadi $80 \%$ pada siklus II. Hal tersebut terjadi karena persentase siswa kategori tinggi meningkat dan diimbangi penurunan persentase kategori sedang dan rendah. Ketercapaian kemampuan berpikir kritis siswa pada siklus I dan siklus II disajikan pada Gambar 7.

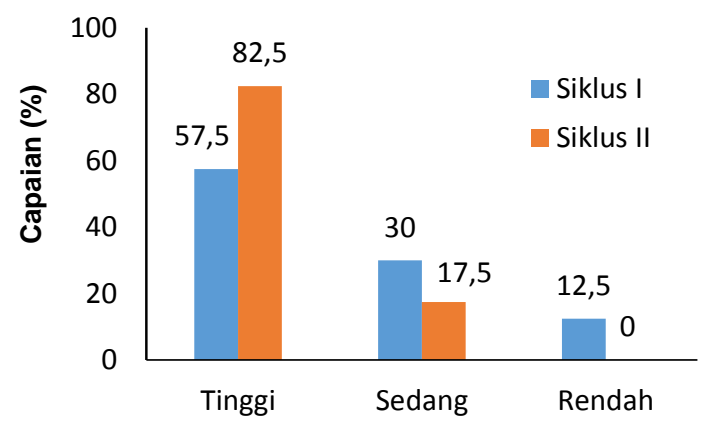

Kategori Kemampuan Berpikir Kritis

Gambar 7. Ketercapaian Kemampuan Berpikir Kritis Siswa pada Siklus I dan II
Perbandingan ketercapaian ketuntasan penilaian aspek pengetahuan siswa pada siklus I dan siklus II disajikan dalam Gambar 8.

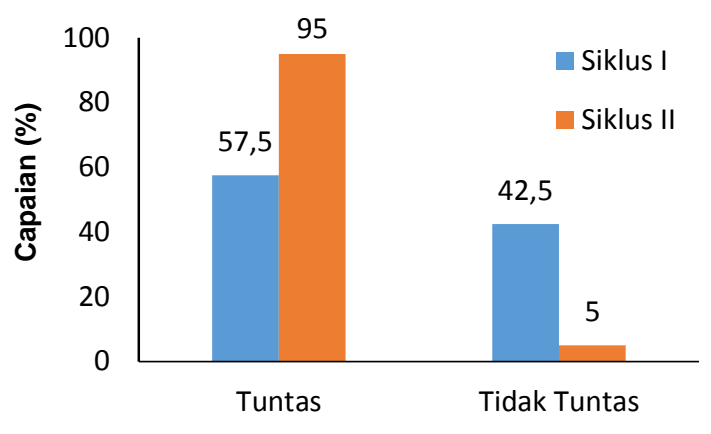

Ketuntasan Aspek Pengetahuan

Gambar 8. Ketercapaian Aspek Pengetahuan Siswa pada Siklus I dan II

Hasil tes aspek pengetahuan pada siklus I dan II menunjukkan bahwa terjadi peningkatan ketuntasan belajar siswa dari $57,5 \%$ pada siklus I menjadi $95 \%$ pada siklus II.

Persentase ketercapian aspek sikap siswa mengalami peningkatan dari siklus I ke siklus II. Pada siklus I, persentase siswa yang memiliki aspek sikap kategori sangat baik dan baik adalah sebesar $80 \%$ dan meningkat menjadi $92,5 \%$ pada siklus II. Ketercapaian aspek sikap siswa pada siklus I dan siklus II disajikan pada Gambar 9.

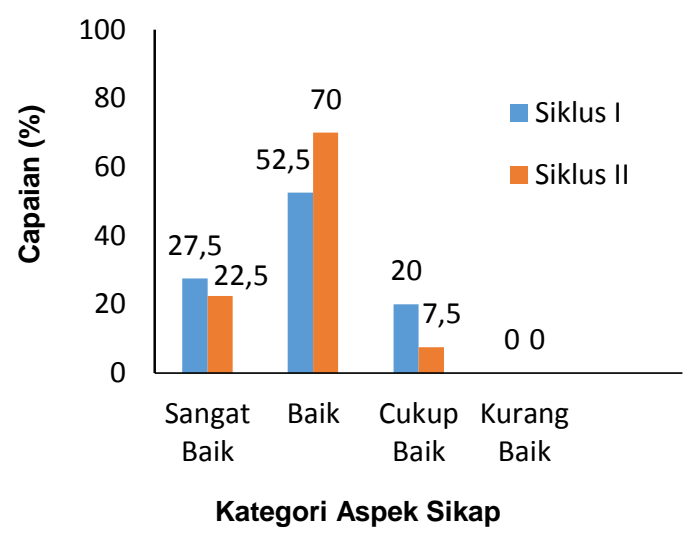

Gambar 9. Ketercapaian Aspek Sikap Siswa pada Siklus I dan II

Hasil penilaian aspek keterampilan siswa pada siklus I menunjukkan bahwa ketercapaian aspek keterampilan siswa adalah sebesar $100 \%$ dan telah men- 
capai target sebesar $75 \%$. Maka dari itu aspek keterampilan siswa tidak dilaksanakan kembali pada siklus II.

Berdasarkan hasil tersebut, penelitian dengan menggunakan model pembelajaran Learning Cycle 7E dikatakan berhasil karena pada akhir penelitian semua aspek telah mencapai target yang ditetapkan. Keberhasilan atas model pembelajaran Learning Cycle $7 E$ juga diungkapkan pada penelitian sebelumnya bahwa model pembelajaran tersebut dapat meningkatkan kemampuan berpikir kritis dalam pembelajaran kimia [3]. Model pembelajaran tersebut juga dapat meningkatkan kemampuan berpikir kritis siswa pada pembelajaran IPA [4]. Selain itu, model pembelajaran LC 7E merupakan model pembelajaran yang sesuai dan berguna dalam pembelajaran IPA [5].

\section{KESIMPULAN}

Hasil dari penelitian yang telah dilakukan dapat disimpulkan bahwa penerapan model pembelajaran Learning Cycle 7E dapat meningkatkan kemampuan berpikir kritis dan prestasi belajar siswa pada sub materi konsep mol kelas X MIA 2 SMA Negeri 1 Sukoharjo tahun pelajaran 2016/2017.

\section{UCAPAN TERIMA KASIH}

Penelitian ini dapat terselenggara dengan baik karena bantuan dari berbagai pihak. Oleh karena itu peneliti mengucapkan terimakasih kepada Kepala SMA Negeri 1 Sukoharjo, Sri Soewarsih, S.Pd., M.Pd. atas izin yang diberikan kepada peneliti untuk melakukan penelitian dan kepada Dra. Haryanti selaku guru kimia kelas $X$ yang telah memberikan bantuan dan arahan selama penelitian.

\section{DAFTAR RUJUKAN}

[1] Triwiyanto, T. (2014). Pengantar Pendidikan. Jakarta: Bumi Aksara.

[2] Anshory, Irfan. (2000). Kimia SMU untuk Kelas 2. Jakarta: Erlangga.
[3] Indrawati, W., Suyatno \& Yuni, S. R. (2015). Pendidikan Sains Pascasarjana Universitas Negeri Surabaya, 5 (1), 788-794.

[4] Hartono. (2013). Jurnal Pendidikan Fisika Indonesia, 9 (2013), 58-66.

[5] Balta, N., \& Sarac, H. (2016). European Journal of Educational Research, 5 (2), 61-72.

[6] Eisenkraft, A. (2003). The Science Teacher. 70 (6), 56-59.

[7] Shaheen, M. N. U. K., \& Kayani, M. N. (2015). Mediterranean Journal of Social Science, 6 (4), 471-481.

[8] Sugiyono. (2013). Metode Penelitian Kuantitatif, Kualitatif dan $R \& D$. Bandung: Alfabeta. 